\title{
Analisis Kemampuan Pemecahan Masalah Siswa Kelas VIII SMPN 1 Rambah Samo Pada Materi Bangun Ruang Sisi Datar
}

\author{
Nuraini $^{1}$, Maimunah², Yenita Roza ${ }^{3}$
}

1), 2), 3) Universitas Riau, Indonesia

CORRESPONDENCE: $\square$ nuraininadhifa14@yahoo.com

\begin{tabular}{|c|c|}
\hline Article Info & Abstract \\
\hline $\begin{array}{l}\text { Article History } \\
\text { Received : 14-05-2019 } \\
\text { Revised : } 19-06-2019 \\
\text { Accepted : 19-06-2019 }\end{array}$ & $\begin{array}{l}\text { The low mathematical problem solving ability of students is seen from the results } \\
\text { of the national exam on mathematics subjects, namely } 43.34 \% \text {. This study aims to } \\
\text { describe the ability to solve mathematical problems based on policy theory which } \\
\text { consists of } 4 \text { stages (1) understanding, (2) planning, (3) solving, and (4) checking. }\end{array}$ \\
\hline $\begin{array}{l}\text { Keywords; } \\
\text { Problem Solving Ability; } \\
\text { Building Space; } \\
\text { Polya Theory }\end{array}$ & $\begin{array}{l}\text { The subjects studied were } 30 \text { students of VIII class. The method used is descriptive } \\
\text { qualitative. Data collection techniques with test and interview methods } \\
\text { Instrument-used } 3 \text { questions which are mathematical problems related to the } \\
\text { surface area and volume of building flat side space. The results of this study } \\
\text { indicate that students who have the ability (1) are very good, often forget to write } \\
\text { what is known and what is asked, (2) at a good level, students have difficulty } \\
\text { understanding and making a mathematical model of the problem editor, ( } 3 \text { ) at a } \\
\text { low level, students make mistakes in calculating, (4) At a very poor level, students } \\
\text { have difficulty understanding and making mathematical models and their } \\
\text { solutions. It is expected to the teacher to give emphasis on understanding the } \\
\text { concept of flat and wake up flat side space when the learning process takes place } \\
\text { and associate it in everyday life, because most students have difficulty in } \\
\text { understanding and making mathematical models of the editorial questions given. }\end{array}$ \\
\hline
\end{tabular}

\section{PENDAHULUAN}

Matematika merupakan ilmu dasar yang dipelajari pada setiap jenjang pendidikan termasuk SMP. Matematika memegang peranan penting karena matematika tidak hanya diterapkan saat belajar matematika itu sendiri tetapi juga diterapkan pada bidang ilmu pengetahuan yang lain[1], [2]. Belajar matematika merupakan satu proses yang terkait dengan ide-ide, gagasan, aturan atau hubungan yang diatur secara logis sehingga dalam belajar matematika harus mencapai pemahaman [3]. Permendiknas No. 22 tahun 2013 menyatakan bahwa tujuan matematika SMP adalah agar siswa mampu memecahkan masalah matematika yang meliputi kemampuan memahami masalah, merancang model matematika, menyelesaikan model dan menafsirkan solusi yang diperoleh. Holmes dalam Sugiyono yang menyatakan bahwa latar belakang atau alasan seseorang perlu belajar memecahkan masalah matematika adalah agar orang tersebut terampil memecahkan masalah sehingga mampu berpacu dengan kebutuhan hidupnya, menjadi pekerja yang lebih produktif, dan memahami isu-isu kompleks yang berkaitan dengan masyarakat global [4].

Rofiqoh menyatakan bahwa kemampuan pemecahan masalah tidak hanya sekedar tujuan pembelajaran matematika namun bahkan merupakan jantungnya matematika [5]. Hal ini berarti, kemampuan pemecahan masalah merupakan kemampuan dasar dalam belajar matematika. Polya dalam Imroatun mengartikan pemecahan masalah sebagai satu usaha mencari jalan keluar dari satu kesulitan guna mencapai suatu tujuan yang tidak begitu mudah untuk dicapai [6]. 
Pemecahan masalah adalah suatu proses atau upaya individu untuk merespon atau mengatasi halangan atau kendala ketika suatu jawaban atau metode jawaban belum tampak jelas [7]. Lebih lanjut, pemecahan masalah dapat berupa menciptakan ide baru, menemukan teknik atau produk baru[8]. Terlihat jelas bahwa belajar pemecahan masalah pada hakekatnya adalah belajar berpikir (learning to think) atau belajar bernalar (learning to reason) yaitu berpikir atau bernalar mengaplikasikan pengetahuan-pengetahuan yang telah diperoleh sebelumnya untuk memecahkan masalah-masalah baru yang belum pernah dijumpai[9]. Melalui proses pemecahan masalah, siswa dapat mengembangkan kemampuan dalam berpikir kritis [7].

Polya dalam Imroatun [6] menyebutkan bahwa terdapat empat langkah fase pemecahan masalah yaitu menganalisis dan memahami masalah (analyzing and understanding a problem), merancang dan merencanakan penyelesaian (designing and planning a solution), menyelesaikan masalah (exploring solution to difficult problem), dan melakukan pengecekan kembali semua langkah yang telah dikerjakan (verifying a solution). Fase memahami masalah ini meliputi membuat gambar atau ilustrasi jika memungkinkan, mencari kasus yang khusus, dan mencoba memahami masalah secara sederhana. Tanpa adanya pemahaman terhadap masalah yang diberikan, siswa tidak mungkin menyelesaikan masalah tersebut dengan benar. Selanjutnya fase merancang dan merencanakan solusi meliputi merencanakan solusi secara sistematis, dan menentukan apa yang akan dilakukan, bagaimana melakukanya serta hasil yang diharapkan. Fase ketiga adalah mencari solusi dari masalah. Dalarn fase penyelesaian masalah sangat tergantung pada pengalaman siswa untuk lebih kreatif dalam menyusun penyelesaian suatu masalah, jika rencana penyelesaian satu rnasalah telah dibuat baik tertulis maupun tidak. Fase mencari solusi ini juga terdiri dari beberapa kegiatan, yaitu: a) menentukan berbagai masalah yang ekivalen yaitu penggantian kondisi dengan yang ekivalen, rnenyusun kembali bagian-bagian rnasalah dengan cara berbeda; menambah bagian yang diperlukan; serta memformulasikan kembali masalah; 2) menentukan dan melakukan memodifikasi secara lebih sederhana dari masalah sebenarnya, yaitu memilih tujuan antara dan mencoba memecahkannya, mencoba lagi mencari solusi akhir, dan memecahkan soal secara bertahap; serta 3) menentukan dan melakukan memodifikasi secara umum dan masalah sebenarnya, yaitu memecahkan masalah yang analog dengan variabel yang lebih sedikit, mencoba menyelsaikan dengan kondisi satu variabel, serta memecahkan masalah melalui masalah yang mirip. Fase terakhir adalah memeriksa solusi yang terdiri darl kegiatan menggunakan pemeriksaan secara khusus terhadap setiap informasi dan langkah penyelesaian dan menggunakan pemeriksaan secara umum untuk mengetahui masalah secara umum dan pengembangannya[10].

Kemampuan pemecahan masalah setiap siswa berbeda-beda, hal ini bisa dilihat dan beberapa hasil penelitian yang telah meneliti kemampuan pemecahan masalah matematika siswa SMP. Emilia dalam penelitiarmya berjudul "Strategi Pemecahan Masalah dalam Menyelesaikan Soal Cerita pada materi SPLDV Siswa Kelas VIII di SMP Kristen 2 Salatiga, menyimpulkan bahwa siswa melakukan tahap understanding sebanyak 35,13\%, pada tahap planning ada 19,23\%, dan tahap solving sebesar 45,64\%, sedangkan tahap checking sebesar $0 \%$. Tidak semua siswa dapat melakukan tahap understanding, planning, solving, dan checking dengan benar, hal itu disebabkan karena pola pikir siswa yang berbeda-beda. Tidak ada satupun siswa yang melakukan tahap checking dikarenakan siswa merasa yakin dengan jawabannya dan tidak adanya pembiasaan dari guru untuk mengecek hasil jawaban[11]. 
Selain itu, adapula penelitian Wahyuningsih yang menunjukkan menunjukkan bahwa terdapat 1 subjek mencapai tahap 1, 5 subjek mencapai tahap 2, 5 subjek mencapai tahap 3, dan 2 subjek mencapai tingkat 4. Pada tingkat I subjek belum mampu memahami masalah, menyusun rencana penyelesaian, melakukan rencana penyelesaian, dan memeriksa kembali, pada tingkat 2 subjek mampu memahami masalah dengan benar, pada tingkat 3 subjek mampu memahami masalah, menyusun rencana penyelesaian, dan melaksanakan rencana penyelesaian, namun tidak memeriksa kembali hasil pekerjaanya, dan tingkat 4 subjek dapat memahami masalah, menyusun penyelesaian, melaksanakan rencana penyelesaian, dan memeriksa kembali dengan benar[12].

Kedua penelitian tersebut menunjukkan bahwa kemampuan pemecahan masalah setiap siswa beragam. Keberagaman kemampuan pemecahan masalah juga dialami oleh siswa kelas VIII A SMP Negeri 1 Rambah Samo. Hasil studi pendahuluan memberikan fakta bahwa tidak semua siswa mampu menyelesaikan masalah. Kondisi ini menuntut adanya langkah mencari solusi kepada siswa. Agar solusi yang diberikan bisa tepat, diperlukan analisis terhadap kemampuan pemecahan masalah siswa. Oleh karena itu, penelitian ini bertujuan untuk menganalisis kemampuan pemecahan masalah matematika siswa kelas VIIIA SMP Negeri 1 Rambah Samo. Penelitian ini akan mendeskripsikan kemampuan pemecahan masalah siswa pada setiap tahap kemampuan pemecahan masalah. Diharapkan penelitian mi dapat dijadikan dasar pemberian bantuan guru kepada siswa yang mengalami permasalahan dalam proses pemecahan masalah matematika.

\section{METODE}

Penelittian ini bertujuan untuk mendeskripsikan kemampuan pemecahan masalah siswa SMP Negeri 1 Rambah Samo pada materi bangun ruang berdasarkan Teori Polya. Jenis penelitian ini adalah penelitian deskriptif kualitatif. Penelitian deskriptif adalah suatu bentuk penelitian yang paling dasar yang bertujuan untuk mendeskripsikan atau menggambarkan fenomena-fenomena yang ada, baik fenomena yang bersifat alamiah ataupun rekayasa manusia. Penelitian kualitatif adalah penelitian yang mengkaji perspektif partisipan dengan multi strategi yakni strategi-strategi yang bersifat bersifat interaktif, seperti observasi langsung, wawancara, dan teknik-teknik pelengkap seperti foto, rekaman, dan sebagainya.

Populasi pada penelitian ini adalah siswa kelas VIII A SMP Negeri 1 Rambah Samo Semester II Tahun Pelajaran 2018/2019 sebanyak 23 siswa. Melalui tes kemampuan pemecahan masalah diambil sampel sebanyak 4 siswa yang memiliki kemampuan pemecahan masalah, sangat baik, baik, cukup dan sangat kurang. Teknik pengumpulan data yang digunakan dalam penelitian ini adalah tes, wawancara, dan dokumentasi. Berikut instrumen tes untuk mengukur kemampuan pemecahan masalah matematika yang digunakan dalam penelitian ini.

1. Sebuah aula berbentuk balok dengan ukuran panjang 8 meter, lebar 6 meter, dan tinggi 5 meter.

Dinding aula bagian dalam dicat dengan biaya Rp 50.000,00 per meter persegi. Berapakah biaya seluruhnya untuk pengecatan aula tersebut?

2. Amir mempunyai sangkar burung berbentuk prisma segi-6 beraturan. Setiap kerangka rusuknya terbuat dari aluminium. Tinggi sangkar burung $60 \mathrm{~cm}$ dan panjang rusuk alasnya 25 cm. Jika harga 1 meter aluminium Rp 20.000,00. Berapa biaya seluruhnya untuk pembelian aluminium tersebut?

Hasil jawaban siswa tersebut dianalisis dan diberi penilaian. Polya dalam Imroatun [6] menyatakan bahwa terdapat empat level kemampuan pemecahan yaitu (1) Sangat baik, kriterianya dapat memahami masalah (menuliskan apa yang diketahui dan yang ditanya), memilih dan 
menggunakan strategi yang jelas dan rasional, membuat model matematika dan perhitungannya dengan tepat, memeriksa kembali jawabannya dengan tepat, (2) Baik dengan kriteria dapat memahami masalah (menuliskan apa yang diketahui dan yang ditanya), memilih dan menggunakan strategi yang jelas dan rasional, membuat model matematika dan perhitungannya dengan tepat, memeriksa kembali jawabannya dengan kurang tepat, (3) Cukup dengan kriteria dapat memahami masalah (menuliskan apa yang diketahui dan yang ditanya), memilih dan menggunakan strategi yang jelas dan rasional, membuat model matematika dan perhitungannya dengan kurang tepat, kurang tepat dalam membuat kesimpulan jawaban, (4) Kurang, kriterianya dapat memahami masalah (menuliskan apa yang diketahui dan yang ditanya), memilih dan menggunakan strategi yang kurang jelas dan rasional, membuat model matematika dan perhitungannya dengan kurang tepat, serata kurang tepat dalam membuat kesimpulan jawaban, (5) Sangat Kurang, kriteria tidak dapat memahami masalah (menuliskan apa yang diketahui dan yang ditanya), tidak memilih dan menggunakan strategi yang jelas dan rasional, tidak membuat model matematika dan perhitungannya,tidak menyelesaikan tugas pemecahan masalah

\section{HASIL DAN PEMBAHASAN}

\section{Hasil Kemampuan Pemecahan Masalah pada Siswa Level Sangat Baik}

Langkah pertama pemecahan masalah menurut Polya adalah memahami masalah. Pada tahap pertama siswa dituntut untuk membuat gambaran atau ilustrasi jika memungkinkan, mencari kasus yang khusus, dan mencoba memahami masalah secara sederhana. Hasil pekerjaan siswa

\section{a. Tahap 1 (Understanding)}

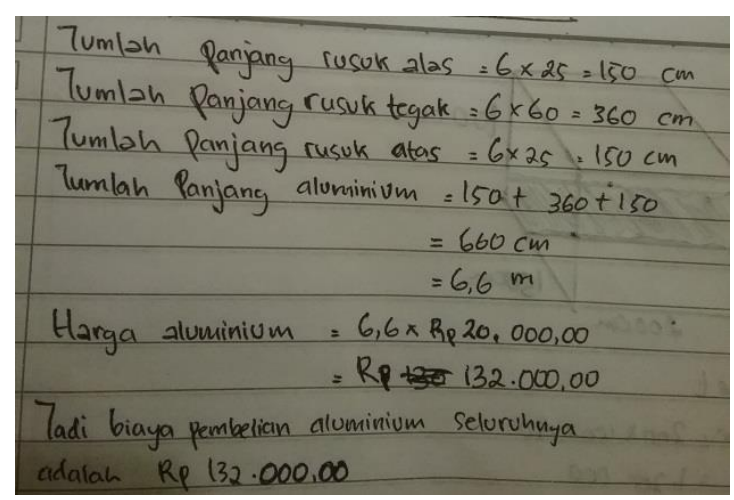

Gambar 1. Hasil Memahami Subjek DE

Tampak pada gambar 1, bahwa siswa kurang lengkap dalam menuliskan informasi yang diketahui dan ditanya, namun ketika wawancara subjek cukup memahami informasi yang terdapat dalam soal. Hal ini dapat dilihat dari kutipan wawancara yang menunjukkan bahwa subjek dapat menceritakan permasalahan dengan bahasa sendiri.

Peneliti

: informasi apa yang kamu peroleh dari soal yang sudah disajikan?

Subjek DE : Amir punya sangkar burung berbentuk prisma segi enam yang terbuat dari aluminium, rusuk prisma yang tegaknya ukurannya $60 \mathrm{~cm}$, trus rusuk alasnya ukurannya $25 \mathrm{~cm}$. Jika harga 1 meter aluminium itu 20.000 rupiah, berapa biaya untuk membeli aluminium selurubnya? 
Dalam wawancara tersebut bahwa subjek DE memiliki kemampuan untuk meahami masalah. Subjek DE tidak menuliskan apa yang diketahui dan apa yang ditanya pada soal, namun subjek DE juga memiliki ketrampilan dalam mengemukakan informasi yang terdapat dalam soal sesuai yang diungkapkan oleh Tambychik dan Meerah (2010) bahwa ketrampilan mengungkapkan fakta bilangan, yaitu dapat memahami informasi yang muncul pada permasalahan.

\section{b. Tahap 2 (Planning)}

Langkah kedua pemecahan masalah menurut Polya adalah merencanakan penyelesaian. Tahap merancang dan merencanakan solusi meliputi merencanakan solusi secara sistematis, dan menentukan apa yang akan dilakukan, bagaimana melakukannya serta hasil yang diharapkan. Pada tahap ini ditemukan bahwa siswa menuliskan rencana penyelesaian pada lembar jawaban, seperi yang terlihat pada lembar jawaban siswa berikut:

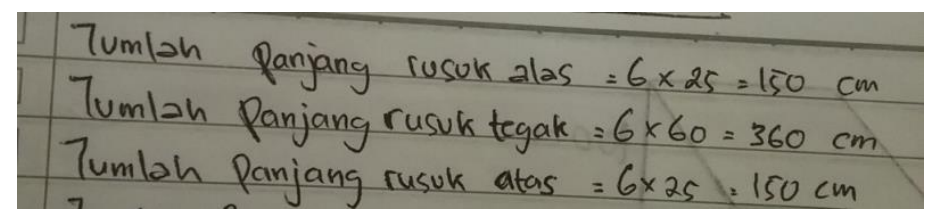

Gambar 2. Hasil Merencanakan Subjek DE

Pada tahap merencanakan subjek DE menuliskan berapa jumlah rusuk seluruhnya, karena pada prisma segienam ada berapa rusuk yang memiliki ukuran yang berbeda-beda. Subjek DE menjelaskannya melalui wawancara berikut:

\section{Peneliti : Bagaimana cara kamu menyelesaikan soal itu?}

Subjek DE : rusuk prisma segi enam itu kan ada 6 yang sisi tegaknya yang ukurannya $60 \mathrm{~cm}$, trus rusuk. alasny a ada 6 yang ukurannya $25 \mathrm{~cm}$, rusuk atas juga sama dengan rusuk alas ada 6 ukurannya juga sama $25 \mathrm{~cm}$. Kemudian saya mengalikan panjang rusuk dengan ukuran yang sudah diketabui masing-masing kan berbeda buk!

Subjek DE tidak menuliskan sepenuhnya rencana penyelesaiaan, namun ketika diwawancarai subjek DE mampu menjelaskan secara runtut dan benar.

\section{c. Tahap 3 (Solving)}

Tahap ketiga adalah mencari solusi dari masalah. Dalam tahap penyelesaian masalah sangat tergantung pada pengalaman siswa untuk lebih kreatif dalam menyusun penyelesaian suatu masalah. Pada tahap terlihat subjek DE menyelesaikan rencana penyelesaian dengan menggunakan prosedur yang benar sehingga hasil yang benar, seperti yang terlihat pada gambar berikut:

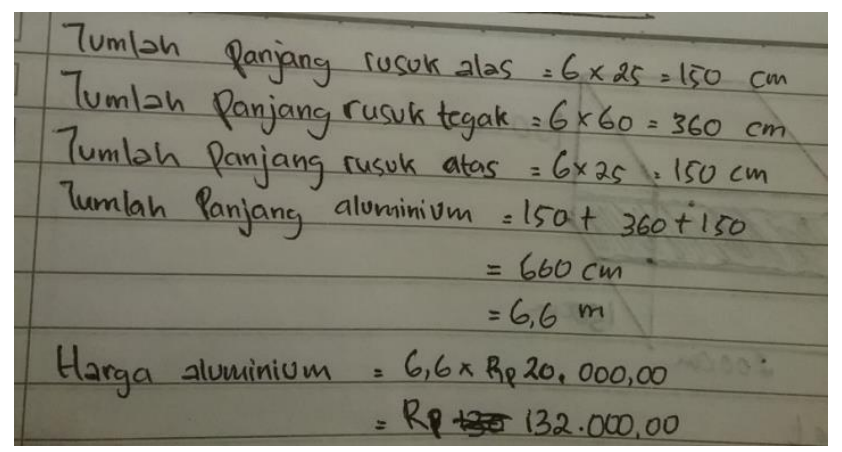

Gambar.3 Hasil Menyelesaikan Subjek DE 
Subjek DE mampu menyelesaikan rencana penyelesaian dengan melakukan perhitungan masing-masing rusuk tegak dikali dengan ukurannya $60 \mathrm{~cm}$, rusuk alas dan rusuk atas dikalikan dengan ukurannya $25 \mathrm{~cm}$. Sesuai dengan hasil wawancara berikut:

Peneliti : Apakah kamu bisa menyelesaikan pada setiap langkah-langkahnya?

Subjek DE : insyaallah bisa bu, saya kalikan aja rusuk tegaknya 6 dikali dengan $60 \mathrm{~cm}$, rusuk alasnya 6 dikali $25 \mathrm{~cm}$, rusuk atas juga sama dengan rusuk alas 6 dikali $25 \mathrm{~cm}$. Setelah dapat semua hasil perkalian baru saya jumlabkan selurub rusuknya, dapatlah saya panjang aluminium selurubnya yaitu $660 \mathrm{~cm}$, karena harga yang diketahui di soal adalah 20.000 rupiah per meternya maka saya barus rubah dulu satuannya menjadi 6,6 m, baru saya kalikan 6,6 dikali 20.000 rupiah!

Saat diwawancarai subjek DE juga mampu menjelaskan dengan tepat, artinya subjek DE mampu menyelesaikan rencana penyelesaiannya dengan baik dan benar dan hasil perhitungan yang dilakukan subjek DE benar dan tepat.

\section{d. Tahap 4 (Checking)}

Tahap terakhir adalah memeriksa solusi yang terdiri dari kegiatan menggunakan pemeriksaan secara khusus terhadap setiap informasi dan langkah penyelesaian dan menggunakan pemeriksaan secara umum untuk mengetahui masalah secara umum dan pengembangannya.

Pada tahap ini siswa melakukan pengecekan terlihat dari hasil kesimpulan jawaban yang ditulis subjek DE. Berikut adalah hasil pekerjakan subjek DE:

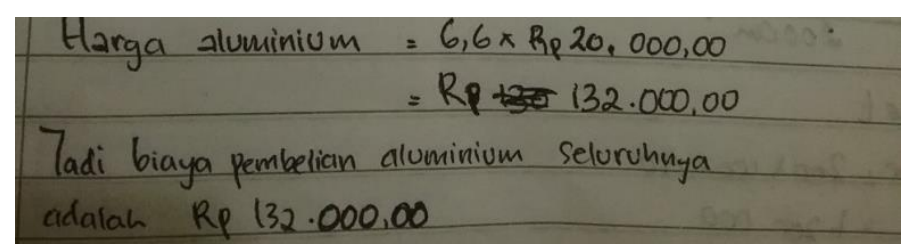

Gambar 4. Hasil Pengecekan Subjek DE

Hasil pengecekan subjek DE didukung hasil wawancara peneliti dan subjek DE berikut ini: Peneliti : Setelah selesai mengerjakan soal, apakab kamu cek kembali hasil jawaban mu itu?

Subjek. DE : iya bu, soalnya tadi awalnya saya menghitungnya salah, saya nggak lihat satuannya, ternyata saya ulang kembali hasil perkaliannya, yang tadinya $660 \mathrm{~cm}$ saya rubah dulu menjadi 6,6 meter, baru saya kalikan dengan 20.000 bu!

Peneliti : apakah kamu mengalami kesulitan dalam menyelesaikan soal yang diberikan?

Subjek DE : Awalnya sih saya bingung bu, tapi setelah saya coba baca ulang lagi soalnya trus saya pabami dan saya bubungkan dengan prisma segienam

Peneliti : : bagaimana cara kamu untuk mengatasi kesulitan itu?

Subjek DE : :saya bitung-bitung lagi, berapa jumlah rusuk pada prisma segienam, trus saya coba ulangi untuk mengalikan lagi sampai basilnya benar-benar meyakinkan saya bu!

Hasil dari pekerjaan dan wawancara subjek DE, memperlihatkan bahwa pada awalnya mengalami kendala dalam menyelesaikan soal yang telah diberikan, Namun subjek DE mampu mengatasi kendala tersebut dengat cara mamahami soal sampai membaca soal lebih dari satu kali. Setelah Subjek DE berusaha memahami kemudian mentransfer pengetahuan dan membuat model matematika dari soal cerita yang telah diberikan.

\section{Hasil Kemampuan Pemecahan Masalah pada Siswa Level Baik}


Langkah pertama pemecahan masalah menurut Polya adalah memahami masalah. Pada tahap pertama siswa dituntut untuk membuat gambaran atau ilustrasi jika memungkinkan, mencari kasus yang khusus, dan mencoba memahami masalah secara sederhana. Hasil pekerjaan siswa

\section{a. Tahap 1 (Understanding)}
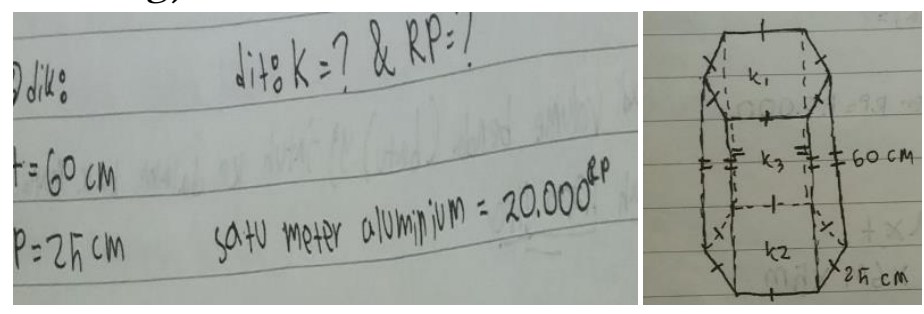

Gambar 5. Hasil Memahami Subjek SR

Tampak pada gambar 5, bahwa siswa lengkap dalam menuliskan informasi yang diketahui dan ditanya, bahkan sampai membuatkan gambar ilustrasinya yaitu gambar prisma segi-6 seperti yang terlihat pada gambar 5. Namun SR salah dalam menuliskan simbol yang ditanya. Hal ini dapat dilihat dari kutipan wawancara yang menunjukkan bahwa subjek dapat menceritakan permasalahan pada soal.

Peneliti : informasi apa yang kamu peroleh dari soal yang sudab disajikan?

Subjek SR : sangkar burung yang berbentuk, prisma segi enam dibuat dari aluminium, dengan ukurannya $60 \mathrm{~cm}$ rusuk prisma yang tegaknya, rusuk alasnya ukurannya $25 \mathrm{~cm}$ sama dengan atasnya dan harga 1 meter aluminium 20.000 rupiah, yang ditanya berapa biaya untuk membeli aluminium selurubnya?

Peneliti : kamu menuliskan dik: $t=60 \mathrm{~cm}, p=25 \mathrm{~cm}$ dan yang dit: $K=$ ? dan $\mathrm{R} P=$ ?, itu maksudnya apa?

Subjek SR : itu maksudnya yang diketahui tinggi prisma $60 \mathrm{~cm}$, panjang rusuk prisma $25 \mathrm{~cm}$, trus yang ditanya itu K, K itu adalah keliling sama dengan jumlah rusuk-rusuk semuanya, kalau RP itu maksudnya adalah berapa rupiah biaya selurubnya!

Dalam wawancara tersebut bahwa subjek SR memiliki kemampuan untuk memahami masalah dan Subjek DE juga menuliskan apa yang diketahui dan apa yang ditanya pada soal lengkap dengan gambarnya. Namun subjek SR kesulitan dalam mentransfer pengetahuan seperti simbol yang ditulis tidak sesuai.

\section{b. Tahap 2 (Planning)}

Langkah kedua pemecahan masalah menurut Polya adalah merencanakan penyelesaian. Tahap merancang dan merencanakan solusi meliputi merencanakan solusi secara sistematis, dan menentukan apa yang akan dilakukan, bagaimana melakukannya serta hasil yang diharapkan. Pada tahap ini ditemukan bahwa siswa menuliskan rencana penyelesaian pada lembar jawaban, seperti yang terlihat pada lembar jawaban siswa berikut: 


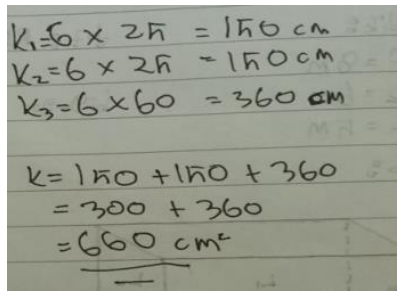

Gambar 6. Hasil merencanakan Subjek SR

Pada tahap merencanakan subjek SR menuliskan K1, K2 adan K3, untuk memberikan simbol pada tahap perencanaan. Subjek SR menjelaskannya simbol-simbol yang digunakan melalui wawancara berikut:

Peneliti $\quad$ : Bagaimana cara kamu menyelesaikan soal itu?

Subjek SR : saya cari dulu K1 untuk rusuk prisma segienam yang bagian alas kan ada 6 saya kalikan dengan $25 \mathrm{~cm}$, trus $K 2$ rusuk bagian atas ada 6 juga saya kalikan dengan $25 \mathrm{~cm}$, trus yang $K 3$ sisi tegaknya ada 6 dikalikan dengan ukurannya $60 \mathrm{~cm}$, gitu saya cara mencarinya buk!

Hasil wawancara Subjek SR mengalami kesulitan dalam membuatkan simbol, tetapi sebenarnya subjek SR memiliki kemampuan dalam memahami serta merencanakan permasalahan dengan runut dan benar

\section{c. Tahap 3 (Solving)}

Tahap ketiga adalah mencari solusi dari masalah. Dalam tahap penyelesaian masalah sangat tergantung pada pengalaman siswa untuk lebih kreatif dalam menyusun penyelesaian suatu masalah. Pada tahap ini terlihat subjek SR menyelesaikan rencana penyelesaian sangat kurang teliti dan simbol yang ditulispun salah. Berikut adalah hasil pekerjaan Subjek SR
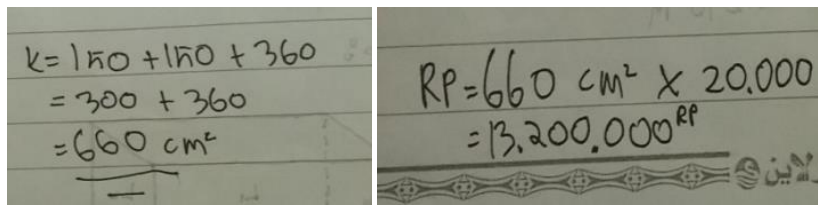

Gambar 7. Hasil Menyelesaikan Subjek SR

Subjek SR mampu menyelesaikan rencana penyelesaian dengan melakukan perhitungan masing-masing rusuk tegak dikali dengan ukurannya $60 \mathrm{~cm}$, rusuk alas dan rusuk atas dikalikan dengan ukurannya $25 \mathrm{~cm}$ :

Peneliti : Apakah kamu bisa menyelesaikan pada setiap langkah-langkahnya?

Subjek DE : bisa bu, setelah saya memperoleb hasil perkaliaan $6 \times 25=150,6 \times 25=150$ dan $6 \times 60$

$=360$, terus saya jumlabkan selurubnya, baru nanti saya kalikan dengan 20.000 dapatlah basilnya 13.200.000

Saat diwawancarai subjek SR mampu memahami dan menjelaskan rencana penyelesaiaan. Namun pada hasil akhir jumlah rusuk secara keseluruhan masih dalam satuan $\mathrm{cm}$. Sedangkan harga pada soal yang diketahui adalah harga 1 meter aluminium.

\section{d. Tahap 4 (Checking)}

Tahap terakhir adalah memeriksa solusi yang terdiri dari kegiatan menggunakan pemeriksaan secara khusus terhadap setiap informasi dan langkah penyelesaian dan menggunakan pemeriksaan secara umum untuk mengetahui masalah secara umum dan pengembangannya. Pada tahap ini subjek SR tidak mengecek kembali hasil pekerjaannya, hal ini terlihat dari gambar 8 berikut: 


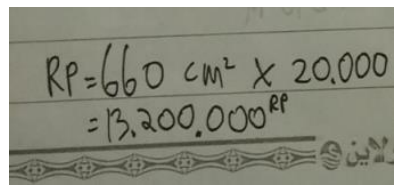

Gambar 8. Tahap Checking Subjek SR

Terlihat pada gambar 8, bahwa subjek SR tidak melakukan pengecekan dari hasil penyelesaian yang telah dilakukan. Hal ini sesuai dengan hasil wawancara peneliti dan subjek SR berikut ini:

Peneliti : Setelah selesai mengerjakan soal, apakah kamu cek kembali hasil jawaban mu itu?

Subjek DE : tidak bu, soalnya tadi saya sudah yakin dengan jawaban saya bu, soalnya saya sudab melakukan perkaliannya yang menurut saya sudah tepat bu!

Peneliti $\quad$ : Tetapi dari hasil jawaban akhir kamu ini salah, kamu tahu dimana kesalahannya?

Subjek SR : : kok salab bu? Saya tidak tahu dimana kesalahannya bu?

Peneliti :Iya kamu kurang teliti dalam menyelesaiakan permasalaban ini, disoal kan yang diketabui harga per meter aluminium, bukan per cm ya!

Subjek SR : ooo iya bu, saya lupa nggak ada ngecek yang satuannya!

Dari hasil wawancara subjek SR tidak melakukan pengecekan dan kurang teliti dalam melakukan perhitunga, eharusnya satuannya dirubah ke meter terlebih dahulu, karena pada soal harga aluminium yang diketahui adalah harga permeter, namun subjek SR menghitungnya dengan harga per $\mathrm{cm}$, yang menyebabkan jawaban akhirnya tidak tepat atau mengalami kesalahan.

\section{Hasil Kemampuan Pemecahan Masalah pada siswa level Kurang}

Langkah pertama pemecahan masalah menurut Polya adalah memahami masalah.

a. Tahap 1 (Understanding)

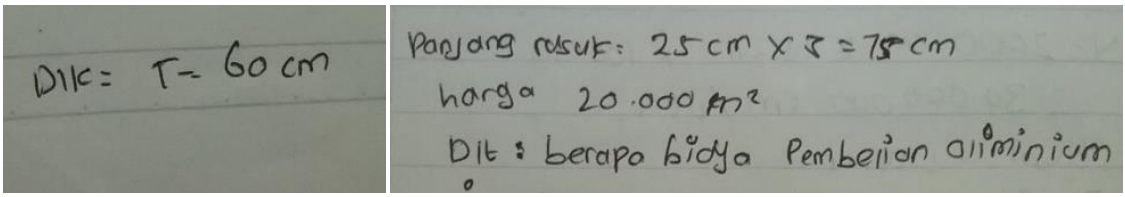

Gambar 9. Hasil Memahami Subjek DM

Tampak pada gambar 9, bahwa siswa lengkap dalam menuliskan informasi yang diketahui dan ditanya, Namun DM salah dalam menuliskan simbol yang diketahui seharusnya r (rusuk bagian tegak) bukan t. Hal ini dapat dilihat dari kutipan wawancara yang menunjukkan bahwa subjek dapat menceritakan permasalahan pada soal.

Peneliti : informasi apa yang kamu peroleh dari soal yang sudah disajikan?

Subjek SR : Amir punya sangkar burung yang berbentuk prisma segi enam yang terbuat dari aluminium, ukuran tingginya $60 \mathrm{~cm}$ itu rusuk prisma yang tegaknya, rusuk alasnya ukurannya $25 \mathrm{~cm}$ atasnya atasnya juga $25 \mathrm{~cm}$, harga 1 meter aluminium 20.000 mupiah,yang ditanya berapa biaya untuk membeli aluminium selurubnya?

Dalam wawancara tersebut bahwa subjek DM memiliki kemampuan untuk memahami masalah dan Subjek DM juga menuliskan apa yang diketahui dan apa yang ditanya pada soal lengkap. Namun subjek DM kesulitan dalam mentransfer pengetahuan seperti simbol yang ditulis tidak sesuai.

\section{b. Tahap 2 (Planning)}

Langkah kedua pemecahan masalah menurut Polya adalah merencanakan penyelesaian. Tahap merancang dan merencanakan solusi meliputi merencanakan solusi secara sistematis, dan 
menentukan apa yang akan dilakukan, bagaimana melakukannya serta hasil yang diharapkan. Pada tahap ini ditemukan bahwa siswa menuliskan rencana penyelesaian pada lembar jawaban, seperti yang terlihat pada lembar jawaban berikut:

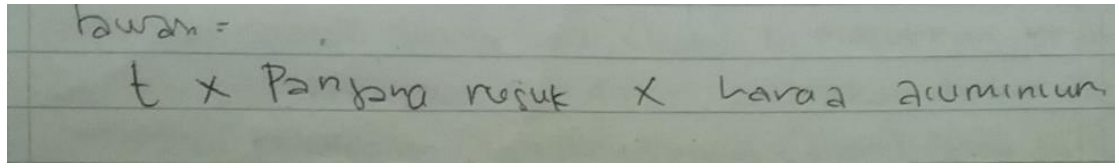

Gambar 10. Hasil merencanakan Subjek DM

Pada tahap ini subjek DM melakukan kesalahan pada tahap perencanaan, rumus yang digunakan tidak sesuai. Kesalahan apa yang dilakukan subjek DM, berikut hasil wawancaranya:

Peneliti $\quad$ : Bagaimana cara kamu menyelesaikan soal itu?

Subjek DM : saya buat rumus dulu yaitu: $t \times$ panjang rusuk $x$ harga aluminium

Peneliti :apakah sudah benar rumus yang kamu gunakan?

Subjek DM : nggak tau bu!

Hasil wawancara Subjek DM mengalami kesulitan dalam membuatkan perencanaan, karena tidak paham dengan konsep pada bangun prisma segi-6, akhirnya subjek DM menuliskan rumus atau perencanaan penyelesaian yang salah.

\section{c. Tahap 3 (Solving)}

Tahap ketiga adalah mencari solusi dari masalah. Dalam tahap penyelesaian masalah sangat tergantung pada pengalaman siswa untuk lebih kreatif dalam menyusun penyelesaian suatu masalah. Pada tahap ini terlihat subjek DM melakukan kesalahan dalam penyelesaiaan karena rumus yang digunakan juga tidak sesuai dengan yang diharapkan soal. Berikut adalah hasil pekerjaan Subjek $\mathrm{DM}$

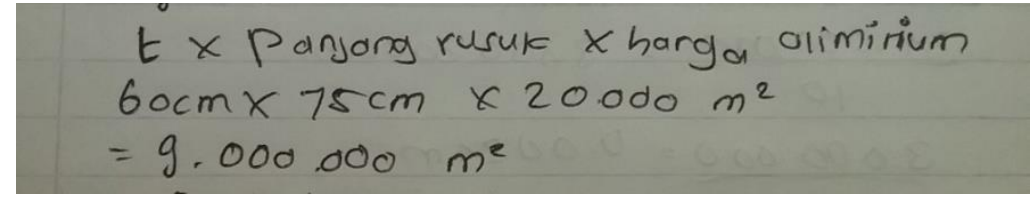

Gambar 11. Hasil Menyelesaikan Subjek DM

Subjek DM melakukan kesalah dalam menyelesaikan rencana penyelesaian dengan karena rumus yang digunakan subjek DM untuk menyelesaiakan pemecahan masalah tersebut tidak sesuai. Hasil wawancara dengan subjek DM

\section{Peneliti : Apakah kamu ingat konsep kerangka bangun prisma segienam?}

Subjek DE : tidak bu, saya lupa bu

Peneliti :nab nanti coba kamu pelajari kembali tentang konsep pada bangun prisma segienam ya, karena kalau kamu tidak paham konsep atau rumusnya maka penyeesaiannya juga jelas salah

Subjek DM : iya bu, terima kasib bu

Saat diwawancarai subjek DM kurang mampu dalam memahami dan menjelaskan rencana penyelesaiaan serta penyelesaian pemecahan masalah.

\section{d. Tahap 4 (Checking)}

Tahap terakhir adalah memeriksa solusi yang terdiri dari kegiatan menggunakan pemeriksaan secara khusus terhadap setiap informasi dan langkah penyelesaian dan menggunakan pemeriksaan secara umum untuk mengetahui masalah secara umum dan pengembangannya. Pada tahap ini subjek DM tidak mengecek kembali hasil pekerjaannya, hal ini terlihat dari gambar 8 berikut: 


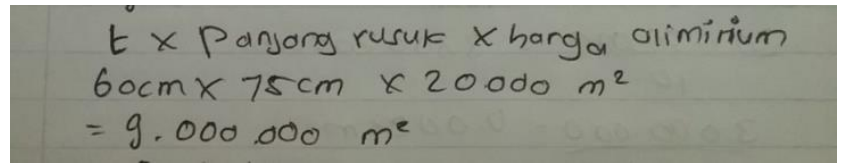

Gambar 12. Tahap Checking Subjek DM

Terlihat pada gambar 12, bahwa subjek DM tidak melakukan pengecekan dari hasil penyelesaian yang telah dilakukan. Hal ini sesuai dengan hasil wawancara peneliti dan subjek DM berikut ini:

Peneliti : apakah kamu cek kembali hasil jawabanmu?

Subjek DM : tidak bu!

Peneliti : rumus yang kamu gunakan salah, maka hasil jawabannya juga salab? Berikutnya harap lebih teliti lagiya

Subjek DM : iya bu

Dari hasil wawancara subjek DM tidak melakukan pengecekan

\section{Hasil Kemampuan Pemecahan Masalah pada siswa level Kurang}

Langkah pertama pemecahan masalah menurut Polya adalah memahami masalah.

\section{a. Tahap 1 (Understanding)}

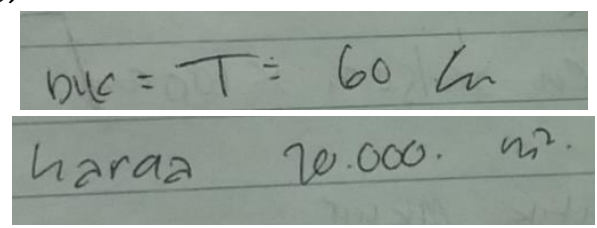

Gambar 13. Hasil Memahami Subjek SM

Tampak pada gambar 13, bahwa siswa tidak lengkap dalam menuliskan informasi, subjek SM hanya menuliskan yang diketahui saja. Hal ini dapat dilihat dari kutipan wawancara yang menunjukkan bahwa subjek dapat menceritakan permasalahan pada soal.

Peneliti : informasi apa yang kamu peroleh dari soal yang sudah disajikan?

Subjek SR : Ada sangkar burung yang bentuknya prisma segi enam, bahannya dari aluminium, ukuran tingginya $60 \mathrm{~cm}$ dan harganya 1 meter aluminium 20.000 rupiah

Dalam wawancara tersebut bahwa subjek SM memiliki kemampuan untuk memahami masalah dan namun Subjek SM hanya menuliskan apa yang diketahui saja.

\section{b. Tahap 2 (Planning)}

Langkah kedua pemecahan masalah menurut Polya adalah merencanakan penyelesaian. Tahap merancang dan merencanakan solusi meliputi merencanakan solusi secara sistematis, dan menentukan apa yang akan dilakukan, bagaimana melakukannya serta hasil yang diharapkan. Pada tahap ini ditemukan bahwa siswa menuliskan rencana penyelesaian pada lembar jawaban, seperti yang terlihat pada lembar jawaban berikut:

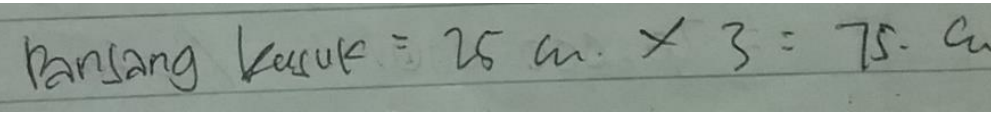

Gambar 14. Hasil Merencanakan Subjek SM

Pada tahap ini subjek SM melakukan kesalahan pada tahap perencanaan, rumus yang digunakan tidak sesuai. Kesalahan apa yang dilakukan subjek SM, berikut hasil wawancaranya:

Peneliti : Bagaimana cara kamu menyelesaikan soal itu? 
Subjek. DM : saya tidak, tau buk, saya buat $25 \times 3=75.000 \mathrm{bu}$

Hasil wawancara Subjek SM mengalami kesulitan dalam membuatkan perencanaan, karena tidak paham dengan konsep pada bangun prisma segi-6, akhirnya subjek SM tidak menuliskan rumus atau perencanaan penyelesaian yang benar

\section{c. Tahap 3 (Solving)}

Tahap ketiga adalah mencari solusi dari masalah. Dalam tahap penyelesaian masalah sangat tergantung pada pengalaman siswa untuk lebih kreatif dalam menyusun penyelesaian suatu masalah. Pada tahap ini terlihat subjek SM tidak melakukan penyelesaiaannya, karena subjek SM belum paham dengan konsep bangun prisma segienam. Berikut adalah hasil pekerjaan Subjek SM

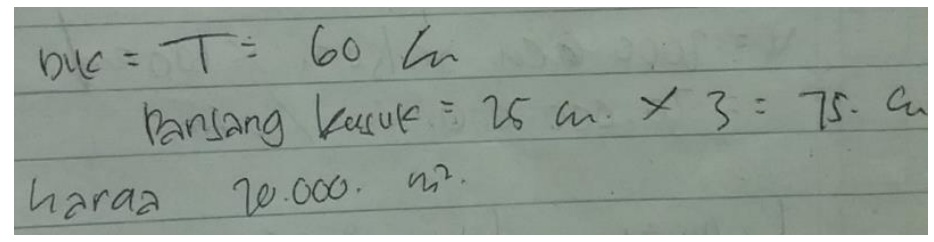

Gambar 15. Hasil Menyelesaikan Subjek SM

Subjek SM tidak melakukan perencanaan maupun menyelesaikan rencana penyelesaian dengan benar. Berikut hasil wawancara dengan subjek SM:

Peneliti : Apakah kamu ingat konsep kerangka bangun prisma segienam?

Subjek DE : tidak bu, saya tidak ingat bu

Peneliti $\quad:$ maksud kamu menuliskan $25 \times 3=75.000$ itu apa?

Subjek DM : saya tidak pabam bu

Saat diwawancarai subjek SM kurang mampu dalam memahami dan menjelaskan rencana penyelesaiaan serta penyelesaian pemecahan masalah.

\section{d. Tahap 4 (Checking)}

Tahap terakhir adalah memeriksa solusi yang terdiri dari kegiatan menggunakan pemeriksaan secara khusus terhadap setiap informasi dan langkah penyelesaian dan menggunakan pemeriksaan secara umum untuk mengetahui masalah secara umum dan pengembangannya. Pada tahap ini subjek DM tidak mengecek kembali hasil pekerjaannya, hal ini terlihat dari gambar 16 berikut:

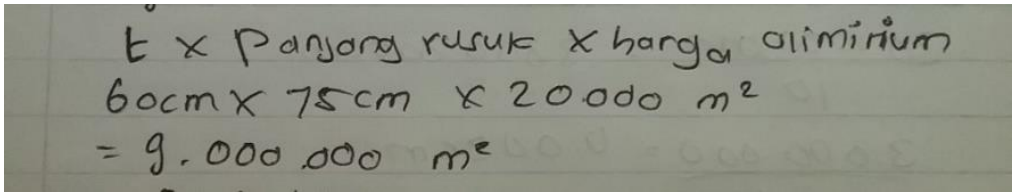

Gambar 16. Tahap Checking Subjek SM

Terlihat pada gambar 16, bahwa subjek SM tidak melakukan pengecekan dari hasil penyelesaian yang telah dilakukan. Hal ini sesuai dengan hasil wawancara peneliti dan subjek DM berikut ini:

Peneliti : apakah kamu cek kembali hasil pekerjaan kamu?

Subjek DM : tidak bu

Peneliti : menurut kamu benar hasil perkalian $25 \times 3=75.000$ ?

Subjek SM : oo iya bu, itu hasilnya 75 bu

Dari hasil wawancara subjek SM tidak melakukan pengecekan kembali terhadap pekerjaannya. 
Berdasarkan penelitian ini ada beberapa faktor yang mempengaruhi tingkatan kemampuan pemecahan masalah pada setiap siswa yaitu siswa kurang memahami konsep bangun ruang, siswa belum melakukan cara yang tepat dalam tahap perencanaan dan perhitungannya, siswa kesulitan dalam membuat model matematika dari soal cerita, siswa belum mampu dalam membuat koneksi dan mentrasfer pengetahuan yang sudah diperolehnya [13][14]. Sejalan dengan pendapat Arumanita [15] bahwa siswa berkemampuan pemecahan masalah pada level sangat baik memiliki kesulitan dalam mentransfer pengetahuan, pada level baik mengalami kesulitan memahami dan menvisualisasikan konsep matematika, pada level siswa yang berkemampuan pemecahan masalah cukup memiliki kelemahan dalam perhitungan dan siswa yang memiliki kemampuan pemecahan masalah sangat kurang mengalami kelemahan dalam membuat koneksi dan lemah dalam perhitungannya.

\section{SIMPULAN DAN SARAN}

Berdasarkan hasil penelitian dan pembahasan serta wawancara, maka dapat disimpulkan bahwa kemampuan pemecahan masalah matematika siswa kelas VIII SMP Negeri 1 Rambah Samo dalam menyelesaikan permasalahan matematika pada materi bangun ruang sisi datar menunjukkan bahwa subjek DE memiliki kemampuan pemecahan masalah di level sangat baik. Subjek DE mampu menyelesaikan dengan tahap Polya secara terurut. Namun subjek DE mengalami kesulitan dalam menuliskan apa yang diketahui dan apa yang ditanya.

Dari hasil tes yang telah dilakukan Subjek SR memiliki kemampuan pemecahan masalah pada tingkatan baik, karena subjek SR telah melakukan teori Polya secara benar dan terurut, namun subjek SR tidak melakukan pengecekan kembali sehingga menyebabkan hasil akhir yang diperoleh terdapat kesalahan. Dalam penyelesaian soal pemecahan masalah, Subjek SR mengalami kesulitan dalam pengecekan kembali hasil yang diperoleh, karena subjek SR kurang teliti dalam memuat sebuah perhitungan.

Melalui tes dan wawancara Subjek DM memiliki kemampuan pemecahan masalah pada tingkatan kurang mengalami kesulitan dalam penggunaan konsep bangun prisma, sehingga subjek DM salah melakukan proses perencanaan. Subjek DM mengalami kesulitan dalam memahami konsep bangun ruang prisma segienam.

Subjek SM memiliki kemampuan pemecahan masalah berada pada tingkatan sangat kurang. Dari hasil tes subjek SM mengalami kesulitan dalam memahami konsep dan membuat sebuah model matematika, sehingga subjek yang memiliki kemampuan pemecahan masalah sangat kurang tidak dapat menyelesaikan pemecahan masalah berdasarkan teori Polya.

\section{DAFTAR PUSTAKA}

[1] M. D. Siagian, "Kemampuan Koneksi Matematik Dalam Pembelajaran Matematika," MES (Journal of Mathematics Education and Science), vol. 2, no. 1, Oct. 2016.

[2] M. Jaeng, "Pendidikan Karakter Melalui Pendidikan Matematika," AKSIOMA Jurnal Pendidikan Matematika, vol. 5, no. 3, Dec. 2016.

[3] Wahyudi dan Inawati Budiono, Strategi Pemecahan Masalah Matematika. Salatiga: Widya Sari Press, 2014.

[4] Sugiyono, Metode Penelitian Pendidikan Pendekatan Kuantitatif, Kualitatif, dan R\&D. Bandung: Alfabeta, 2016. 
[5] Z. Rofiqoh, "Rofiqoh, ZemAnalisis Keinampuan Pemecahan Masalah Siswa Kelas X Dalam Pembelajaran Discovery Learning Berdasarkan Gaya Belajar Siswa," Universitas Negeri Semarang, 2015.

[6] Siti Imroatun, "Straregi Pemecahan Masalah Matematika Siswa Kelas VII SMP Kristen 2 Salatiga ditinjau dari Langkah Polya," 2014.

[7] E. S. Indrajaya, "Strategi Pemecahan Masalah Dalam Menyelesaikan Soal Cerita Pada Materi SPLDV Siswa Kelas VIII Di SMP Kristen 2 Salatiga," Universitas Kristen Satya Wacana Salatiga, 2015.

[8] M. S. Anwar, "Efektifitas Pembelajaran PBL (Problem Based Learning) Terhadap Kemampuan Berpikir Kritis Dan Kreatif Siswa Materi Tiga Dimensi," masters, Universitas Terbuka, 2015.

[9] A. D. Susandi and S. Widyawati, "Proses Berpikir dalam Memecahkan Masalah Logika Matematika Ditinjau dari Gaya Kognitif Field Independent dan Field Dependent," 1, pp. 93112, Jul. 2017.

[10] Syaharuddin, "Description On The Ability To Solve Mathematics Problem In Relation To Concept Comprehension Based On Learning Styles Of Grade VIII Students At SMPN 4 Binamu In Jeneponto District," Program Pascasarjana Universitas Negeri Makassar, Makasar, 2016.

[11]E. Silvi Indrajaya, N. Ratu, and Kriswandani, "Strategi Pemecahan Masalah Dalam Menyelesaikan Soal Cerita Pada Materi SPLDV Siswa Kelas VIII di SMP Kristen 2 Salatiga," Universitas Kristen Satya Wacana, Salatiga, 2015.

[12] B. Y. Wahyuningsih, "Pemecahan Masalah Matematika Melalui Metakognisi Dalam Konteks Sosial," Jurnal Kependidikan: Jurnal Hasil Penelitian dan Kajian Kepustakaan di Bidang Pendidikan, Pengajaran dan Pembelajaran, vol. 17, no. 1, Jul. 2018.

[13] I. Masitoh, "Peningkatan Pemahaman Konsep Matematika Dan Kemampuan Berpikir Kritis Matematis Siswa Kelas V Sekolah Dasar Melalui Pembelajaran Eksploratif," Pascasarjana Universitas Pendidikan Indonesia, Bandung, 2016.

[14]D. G. Prasetyawan, "Diagnosis Kesulitan Belajar Matematika Siswa Kelas IV SD Negeri Congkrang 1 Muntilan Magelang," Universitas Negeri Yogyakarta, Yogyakarta, 2016.

[15] Arumanita, "Kemampuan Pemecahan Masalah Siswa SMP Negeri 1 Papar Pada Materi Bangun Ruang," Jurnal Math Educator Nusantara (JMEN), vol. 4, no. 2, pp. 104-124, 2018. 